National Marine

Fisheries Service

NOAA
Fishery Bulletin

a established in 1881 a
Spencer F. Baird

First U.S. Commissione of Fisheries and founder of Fishery Bulletin
Abstract-Surveys of juvenile and larval stages can be useful for management of commercially important marine fishes but require definitive species identification. From May through October 2005-2008, midwater $(30-\mathrm{m})$ trawls collected 78,407 late-larval and juvenile rockfish ( $\mathrm{Se}$ bastes spp.) in shelf and slope waters off Oregon and Washington. Because of their small size and lack of pigmentation, we could identify only $4.1 \%$ (3266 individuals) of sampled rockfishes to species morphologically, representing a total of 17 species. An additional subsample (2534 individuals), representing 24 species and a 4-species complex, was identified by sequencing the mitochondrial cytochrome $b$ gene and matching sequences to a reference data set. Incomplete overlap between identified species meant that a total of 29 species were identified overall. Community analyses showed that rockfish collected during the early upwelling season (May-June) were distinct from samples collected in the late upwelling season (July-October). Most rockfish were collected from outer-shelf or upper-slope stations, but distributions varied by month and year. Combining genetic and morphological identifications vastly improved our ability to assess seasonal distributions and abundances of planktonic rockfishes and is a step toward performing species-level surveys for this speciose and commercially important genus. Definitive identification based on visual and molecular methods as used here provides key information to enhance understanding of early-stage rockfish ecology.

Manuscript submitted 20 December 2017. Manuscript accepted 19 June 2018.

Fish. Bull. 116:266-280 (2018)

Online publication date: 10 July 2018. doi: 10.7755/FB.116.3-4.5

The views and opinions expressed or implied in this article are those of the author (or authors) and do not necessarily reflect the position of the National Marine Fisheries Service, NOAA.

\section{Seasonal distribution of late larval and juvenile rockfish (Sebastes spp.) and associated environmental conditions off Oregon and Washington: new insights based on genetics}

\author{
Mattias L. Johansson ${ }^{1}$ \\ Marisa N.C. Litz ${ }^{2}$ \\ Richard D. Brodeur ${ }^{3}$ \\ Tristan A. Britt ${ }^{2}$ \\ Camilo A. Vanegas ${ }^{1}$ \\ John R. Hyde 4 \\ Michael A. Banks ${ }^{1}$ \\ Email address for contact author: m.l.johansson@gmail.com \\ ${ }^{1}$ Coastal Oregon Marine Experiment Station \\ Oregon State University \\ 2030 SE Marine Science Drive \\ Newport, Oregon 97365 \\ Present address for contact author: Biology Department \\ University of North Georgia \\ 3820 Mundy Mill Road \\ Oakwood, Georgia 30566 \\ 2 Cooperative Institute for Marine Resources Studies \\ Oregon State University \\ 2030 SE Marine Science Drive \\ Newport, Oregon 97365 \\ ${ }^{3}$ Fish Ecology Division \\ Northwest Fisheries Science Center \\ National Marine Fisheries Service, NOAA \\ 2030 S Marine Science Drive \\ Newport, Oregon 97365-5296 \\ ${ }^{4}$ Fisheries Resources Division \\ Southwest Fisheries Science Center \\ National Marine Fisheries Service, NOAA \\ 8901 La Jolla Shores Drive \\ La Jolla, California 92037-1509
}

The larval and juvenile stages of many demersal fish species occur in pelagic waters, which may connect populations (Cowen and Sponaugle, 2009), and may promote survival of a subset of larval production by dispersing larvae among diverse habitats in an uncertain, variable environment while reducing the risk of inbreeding and density-dependent mortality (Gadgil, 1971; Levin et al., 2003). The dispersal of most larval fish seems to be highly diffusive and driven by ocean currents, although there is evidence that some rockfishes (particularly nearshore spe- cies) remain nearshore due to larval swimming behavior or limited water movement (Buonaccorsi et al., 2002, 2005; Johansson et al., 2008). Environmental conditions also vary with ocean currents, and habitat variability can affect species abundance and diversity.

In the California Current system of the eastern North Pacific, the genus Sebastes (the rockfishes) is known to be sensitive to shifts in environmental conditions associated with changes in prevailing currents. The rockfishes are among the most common of groups found in pelagic 
micronekton surveys in the eastern North Pacific. Larval and juvenile rockfishes may represent a great deal of unrecorded diversity because they are often difficult or impossible to identify to species based on body shape or pigmentation patterns. This highly diverse genus is represented by at least 65 species in the Pacific Ocean off the coast of North America, of which 36 to 40 occur in waters off southern Washington and northern Oregon (Love et al., 2002).

After parturition, the life history of all rockfish species includes a pelagic phase, consisting of both larval and juvenile stages (Boehlert, 1977; Moser and Boehlert, 1991). Settlement to the bottom occurs after a period of a few months to a year, and varies by species (Love et al., 2002). Larval and pelagic-juvenilestage rockfish represent a significant proportion of the ichthyoplankton and micronekton community off Washington, Oregon, and California (Auth, 2009; Phillips et al., 2009; Thompson et al., 2016; Thompson et al., 2017).

The early-stage larvae of a number of species of rockfish occurring off the west coast of North America have been described morphologically (Sakuma and Laidig, 1995; Moser, 1996). However, misidentification of larval and juvenile fish often occurs even at the family level (Ko et al., 2013). Visual identification of field-caught late-larval and early-juvenile rockfishes is especially difficult because different but closely related species of Sebastes occur together and there are few distinguishing morphological characters (Seeb and Kendall, 1991; Sakuma and Laidig, 1995; Rocha-Olivares et al., 2000). This difficulty of identifying late larval and juvenile rockfishes is particularly problematic given their importance in the fisheries they support in the northeast Pacific Ocean (Love et al., 2002) and their history of being heavily fished.

Surveys of pelagic larval and juvenile fish are a widely used fishery-independent means of tracking abundances of marine fishes (Lasker, 1985; He et al., 2015). These surveys are both easier and cheaper than sampling adult fishes, and are likely to have a smaller impact on populations. In order to provide early indications of the potential recruitment of fishes to the northern California Current, the NOAA Northwest Fisheries Science Center (NWFSC) Fish Ecology Division has conducted surveys as part of the Stock Assessment Improvement Program (SAIP) during summer from 2004 through 2012 to collect late-larval and juvenile fish from southern Washington to central Oregon (Phillips et al., 2009).

The ability to efficiently identify large numbers of individual late-larval and pelagic juvenile rockfish would make it possible to characterize the distributions and abundances of the early life stages of species (Love et al., 2002; Ralston and Stewart, 2013), as well as conduct associated recruitment studies and estimate juvenile biomass (Sakuma and Laidig, 1995; Laidig et al., 2007). Molecular methods based on allozyme, microsatellite, or DNA sequence variation offer an alternative to morphological approaches to identify larvae to species quickly and efficiently (Seeb and Kendall, 1991; Rocha-Olivares et al., 2000; Gharrett et al., 2001; Taylor et al., 2004; Gray et al., 2006).

Our objectives were to identify to species late-stage larvae and juveniles of the genus Sebastes collected in SAIP tows of midwater trawls made during 2005-2008 by using visual meristic or pigmentation patterns. We used the cytochrome $b$ sequence-based method of Taylor et al. (2004) to identify to species the remaining visually unidentifiable fraction. Using both of these techniques, we also sought to assess spatial and temporal variations in composition, concentration, and other characteristics of the late-larval and juvenile rockfish community off the coast of Oregon and Washington, and to relate their distributions to environmental conditions during the main upwelling season (May-October).

\section{Materials and methods}

\section{Sampling procedure}

Midwater trawls were used to sample micronekton, including juvenile fishes, from spring to fall during 20052008. With the exception of May 2005 and July 2006, monthly cruises were conducted from May through September of each year, and an additional cruise was included from October 2005. In each sampling cruise, the same 5 stations were sampled along each of 4 transects: Heceta Head $(\mathrm{HH})\left(44.00^{\circ} \mathrm{N}\right)$, Newport $(\mathrm{NH})$ $\left(44.65^{\circ} \mathrm{N}\right)$, and the Columbia River $(\mathrm{CR})\left(44.16^{\circ} \mathrm{N}\right)$ off Oregon and Willapa Bay (WB) $\left(46.67^{\circ} \mathrm{N}\right)$ off Washington (Fig. 1). Stations ranged from approximately 20 to $100 \mathrm{~km}$ offshore along each transect. A single station, located $185 \mathrm{~km}$ (100 nautical miles) off the $\mathrm{NH}$ transect (the NH-100 station) was sampled just once in June 2008. Owing to weather or mechanical problems, some stations or transects (or both) were not sampled during some cruises.

To collect the samples used in this project, a Nordic 264 rope trawl was towed for 15 min with the head rope at a target depth of $30 \mathrm{~m}$. The effective mouth area of the trawl was $12 \mathrm{~m}$ high and $28 \mathrm{~m}$ wide (336 $\mathrm{m}^{2}$; Emmett et al., 2004). The main body of the net had variable mesh sizes (from $162.6 \mathrm{~cm}$ at the mouth to $8.9 \mathrm{~cm}$ at the codend), and a 6.1-m long, $3-\mathrm{mm}$ stretched knotless web liner in the codend. All tows of the trawl were conducted at night. After all fish and invertebrates $>10 \mathrm{~cm}$ in total length were removed, the remaining catch was subsampled as follows: samples with an unsorted volume of $\leq 0.25 \mathrm{~m}^{3}$ were frozen in their entirety, whereas samples with an unsorted volume of $>0.25 \mathrm{~m}^{3}$ were subsampled in the amount of $0.25 \mathrm{~m}^{3}$ or $20 \%$ of the entire sample, whichever was larger. The retained unsorted catches were frozen at sea and later thawed and sorted in the laboratory. For additional details on the collection method, see Phillips et al. (2007).

In the laboratory, individual rockfish were identified to the lowest possible taxonomic level by using a va- 


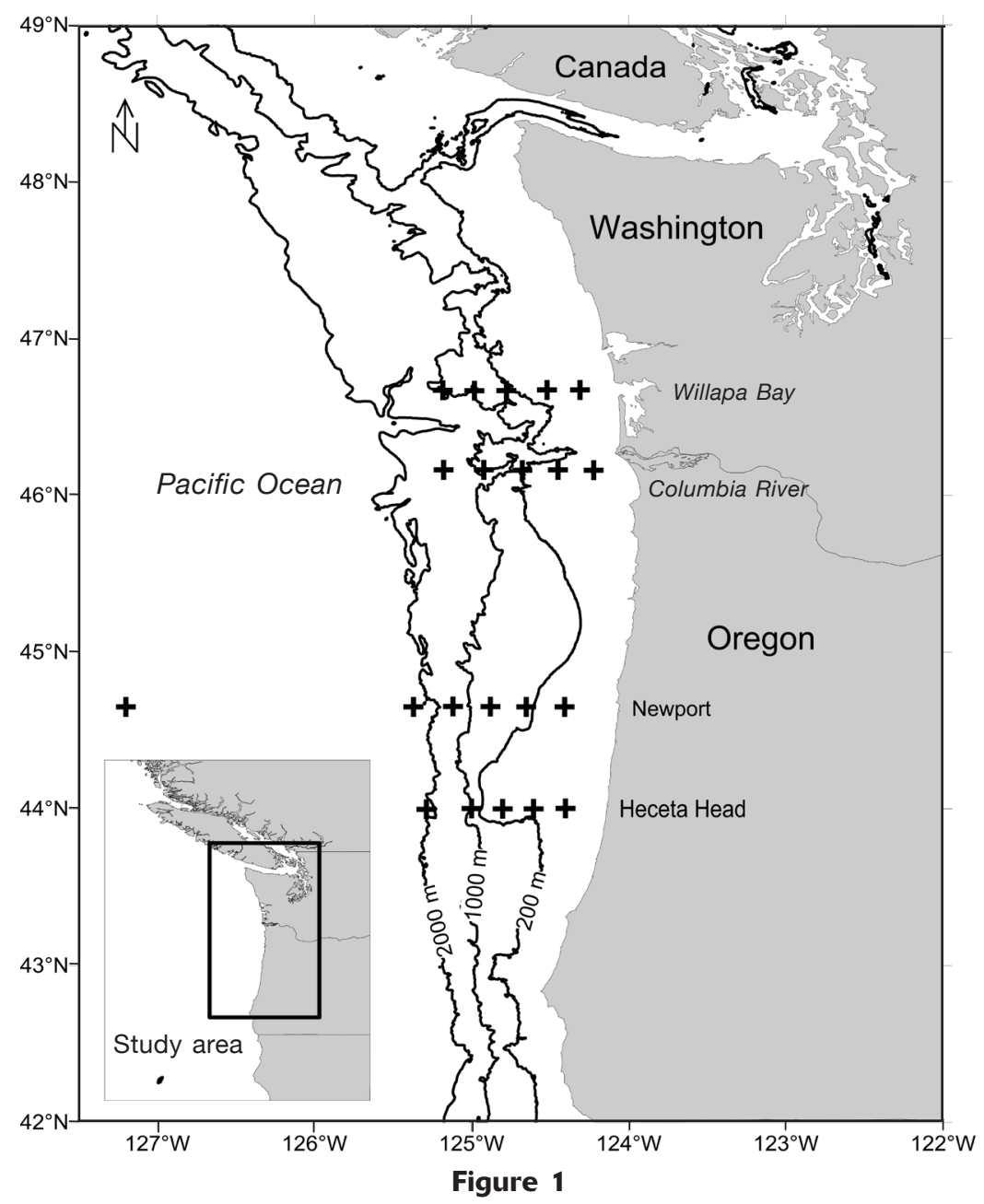

Map of stations (+) off Oregon and Washington sampled for species of Sebastes during 2005-2008. Along transects at Heceta Head, Newport, the Columbia River, and Willapa Bay, 5 stations were sampled during most sampling cruises. In addition, a single station located $185 \mathrm{~km}$ from shore on the Newport transect (the NH-100 station) was sampled once in June 2008.

riety of keys (Richardson and Laroche, 1979; Laroche and Richardson, 1980, 1981; Matarese et al., 1989; Laidig and Adams, 1991; Moser, 1996) and measured for standard length (SL, to the nearest $\mathrm{mm}$ ). Densities for visually identified species were calculated by dividing catch by total distance towed $(\mathrm{km})$ and assuming a relatively constant mouth opening for all the tows. Because of ambiguous and overlapping meristics, most (96\%) late-larval and juvenile rockfishes could be identified only to the genus Sebastes and were stored in ethanol for genetic analysis.

\section{DNA extraction and data collection}

To perform genetic analysis, we took samples from caudal fin tissue of late-larval and juvenile rockfish (2534 individuals) collected in 144 different tows of the trawl. Samples were randomly selected from among the $96 \%$ of samples that could not be identified visually. On av- erage, $26 \%$ of the individual rockfish from each haul were sampled for genetic material to obtain a representative sample of catch. Total genomic DNA was extracted by using a glass-fiber plate extraction protocol (Ivanova et al., 2006). Polymerase chain reaction (PCR) was used to amplify a 782-base-pair (bp) fragment of the mitochondrial DNA (mtDNA) cytochrome $b$ gene by using previously published GluRF and CB3RF primers (Rocha-Olivares et al., 1999). Thermal cycling conditions included an initial denaturation at $94^{\circ} \mathrm{C}$ for 2.5 min, followed by 35 cycles of $94^{\circ} \mathrm{C}$ for $45 \mathrm{sec}, 56^{\circ} \mathrm{C}$ for $1.5 \mathrm{~min}$, and $72^{\circ} \mathrm{C}$ for $1.5 \mathrm{~min}$. Final extension was carried out at $72^{\circ} \mathrm{C}$ for $3 \mathrm{~min}$. PCR products were cleaned using a procedure with ExoSap-IT ${ }^{1}$ reagent (Thermo Fisher Scientific, Waltham, MA), and were cycle se-

\footnotetext{
${ }^{1}$ Mention of trade names or commercial companies is for identification purposes only and does not imply endorsement by the National Marine Fisheries Service, NOAA.
} 
quenced by using BigDye Terminator cycle sequencing kits (Thermo Fisher Scientific) and internal primers CBInf2 and CBInr2 (Dauble et al., 2012). Sequencing products were cleaned with Sephadex (GE Healthcare Bio-Sciences, Pittsburgh, PA) and visualized on an Applied Biosystems 3730xl DNA Analyzer (Thermo Fisher Scientific). Sequence data were aligned and edited with Sequencher, vers. 4.7 (Gene Codes Corp., Ann Arbor, MI) software. All sequencing and analysis were performed by the authors. Reference and unknown sequence data are available from ScholarsArchive@OSU (available at website).

Haplotype sequences from trawl-collected larvae were compared with a reference data set of 374 independent haplotypes from 67 species of morphologically identified adult rockfish (see Taylor et al., 2004 for species included in the reference data set). Identical sequences were identified in Sequencher, and all unique sequences were compared with the reference data set by using a custom script in $\mathrm{R}$, vers., 3.3.1 ( $\mathrm{R}$ Core Team, 2016) and the program PAUP*, vers. 4b10; Sinauer Associates, Sunderland, MA) with the optimality criterion set to distance (number of bp differences divided by total length of sequence in $\mathrm{bp}$ ).

Nonparametric bootstrapping (1000 replicates) was used to cluster individual unknown sequences within the reference data set of 374 known adult sequences. Some species in the reference data set failed to form monophyletic clades: the widow rockfish ( $S$. entomelas) and blue rockfish (S. mystinus) (EM complex) and pygmy rockfish (S. wilsoni), Puget Sound rockfish $(S$. emphaeus), harlequin rockfish (S. variegatus), and sharpchin rockfish (S. zacentrus) (WEVZ complex). Others, such as the splitnose rockfish (S. diploproa), have few differences from sister species, a feature that affects the robustness of bootstrap results. For samples that were identified as falling within the EM complex, we manually compared sequences in Sequencher with those of known widow rockfish and blue rockfish. Known widow and blue rockfish differ consistently at a single nucleotide in our database of known sequences (base position 627, where widow rockfish sequences contain a cytosine and blue rockfish sequences contain an adenine), allowing us to identify all our juveniles as widow rockfish. For all other samples, we performed identifications with 2 different levels of stringency and compared outcomes. If an individual clustered within a monophyletic single-species clade with a bootstrap value $\geq 70 \%$, this result was considered a high-confidence identification of the individual. Bootstrap values between $50 \%$ and $69 \%$ were considered low-confidence identifications. Other outcomes (i.e., nonmonophyletic affinities, polytomies) were coded as failed identifications. We also calculated F84 distance (Felsenstein and Churchill, 1996) between unknown and reference haplotypes using the $R$ package ape, vers. 3.5 (Paradis et al., 2004) to confirm that unknowns fell within the range of expected intraspecific diversity on the basis of reference data.

\section{Physical data}

Physical data were collated from local, regional, and basin-wide spatiotemporal scales for comparison with rockfish community composition to determine whether species of Sebastes were associated with a particular level of environmental variability. In situ measurements of temperature and salinity were collected at the surface $(1 \mathrm{~m})$ and at trawling depth $(30 \mathrm{~m})$ by using a cast of an SBE25plus Sealogger CTD conductivity, temperature, and pressure recorder (Sea-Bird Scientific, Bellevue, WA) at each sampling station. At the regional scale, monthly averaged upwelling indices, based on estimates of offshore Ekman transport driven by geostrophic wind stress at $45^{\circ} \mathrm{N}$ and $145^{\circ} \mathrm{W}$, were obtained from the Pacific Fisheries Environmental Laboratory (website). At the basin scale, monthly indices of the Pacific Decadal Oscillation (PDO; Mantua et al., 1997) and the North Pacific Gyre Oscillation (NPGO; Di Lorenzo et al., 2008) were included in the analysis because they are oceanic expressions of the 2 dominant modes of North Pacific atmospheric variability-the Aleutian Low and the North Pacific Oscillation, which are linked to the different phases of the El Niño Southern Oscillation cycle (Di Lorenzo et al., 2010). The PDO captures variability in sea-surface temperature (SST) and the NPGO captures the variability in salinity, nutrients, and chlorophyll- $a$.

\section{Community analyses}

To evaluate seasonal and annual variability in the species numerical composition of late-larval and juvenile rockfish sampled for this study, nonmetric multidimensional scaling (NMS) was used to ordinate rockfish samples (densities of fish identified in the laboratory by visual means and proportions of rockfish identified on the basis of genetics) in $n$-dimensional space. NMS is an iterative process that searches for the best positions of $n$ entities on $k$ dimensions (axes) that minimize the stress of the $k$-dimensional configuration (McCune et al., 2002). The goal is to generate a plot of sample points (individual tows) such that the rank order of the dissimilarity values between all pairs of samples is preserved in the spatial arrangement of points in the final plot. A total of 17 rockfish species were visually identified in the laboratory from 3266 individuals collected at 93 sampling stations, but only 7 taxa that occurred in $\geq 10 \%$ of the sampling stations were included in the analysis (total number of individuals of the 7 visually identified taxa: 3072$)$. Densities were $\ln (x+1)$ transformed and relativized by species maxima to homogenize variance. For rockfishes identified by using genetics, 24 taxa (total number of individuals of the 24 genetically identified taxa: 915) were used, excluding individuals classified to species complexes as WEVZ (1489 individuals) or samples for which identification to species failed (25 individuals). This analysis was conducted with PC-ORD, vers. 6; MjM Software, Gleneden Beach, OR; McCune and Mefford, 2011) with 


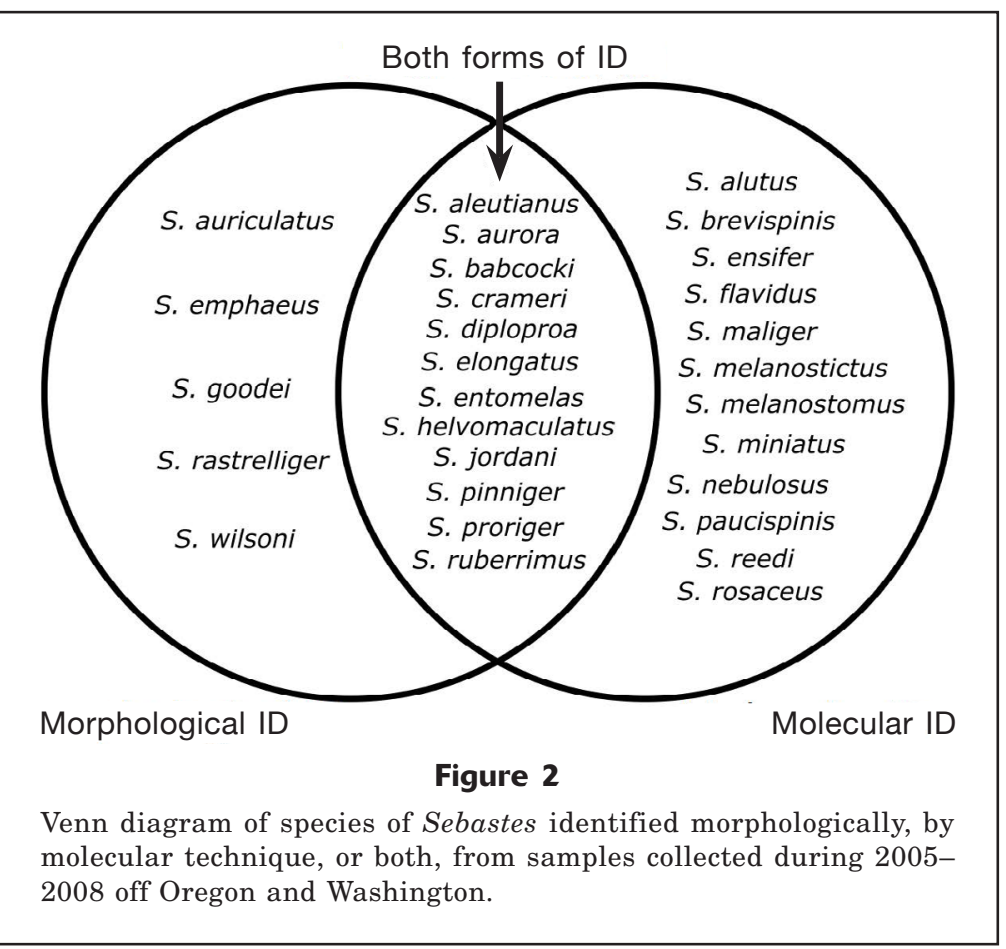

\section{Results}

\section{Rockfish identification}

Late-larval and juvenile rockfish were caught in 196 of the 271 tows made $(72 \%)$ for a total of 78,407 specimens from 2005 through 2008. Using strictly visual means (meristics and pigmentation), we were able to identify 3266 (4.1\% of total) late-larval/ juvenile rockfish from 17 distinct taxa found in 93 hauls (Fig. 2). By far the most abundant species ( $81 \%$ of the identified rockfish) was the rosethorn rockfish ( $S$. helvomaculatus), of which 2633 were identified. Other abundant rockfish species identified visually were the greenstriped rockfish ( $S$. elongatus, 213 individuals), rougheye rockfish (S. aleutianus, 72 individuals), redbanded rockfish (S. babcocki, 66 individuals), brown rockfish (S. auriculatus, 66 individuals), and darkblotched rockfish (S. crameri, 52 individuals). Collectively, these 6 species accounted for $95 \%$ of the fish visually identified from 2005 through 2008.

Size distributions of late-larval and juvenile rockfish measured during this study

the Sørensen distance measure, a maximum of 4 axes, and 200 iterations.

We examined monthly averages of temperature, salinity, and large-scale environmental indices by year to assess how the physical environment varied during the study. To determine the degree to which these variables were correlated with one another, we used Pearson correlation analysis. We also used correlation analysis to assess the relationship of the environment with the juvenile rockfish community by examining relationships between NMS scores and environmental covariates measured at the level of an individual haul. Physical variables included surface $(1 \mathrm{~m})$ and depth (30 m) temperature and salinity, as well as the largescale indices of upwelling, PDO and NPGO. Distance from shore $(\mathrm{km})$ was included as a spatial variable in the multivariate analysis because it has been shown in other studies that ichthyoplankton communities can vary along inshore and offshore gradients (Auth et al., 2011). Temporal variables included month, year, and season (spring=May and June, summer=July-October).

We also conducted indicator species analysis on each rockfish species matrix to detect within- and betweenyear variability and to identify statistically significant indicators for each month and year (Dufrêne and Legendre, 1997). An indicator species analysis combines information on relative abundance and frequency of occurrence to identify indicators that are most characteristic of a group. Indicator species analysis was performed separately for sampling months and years. Levels of significance were determined by using a Bonferroni adjustment and based on Monte Carlo tests with 5000 permutations for comparison with observed indicator values. ranged from 6 to $69 \mathrm{~mm}$ SL (Suppl. Figs. 1 and 2). There was a tendency toward greater visual identification of larger individuals, especially in May, when all specimens $>35 \mathrm{~mm}$ SL were identifiable but none below this threshold (Suppl. Fig. 1). Similar patterns were observed in the annual size ranges that could be identified by visual means (Suppl. Fig. 2).

Subsampling among the visually unidentifiable larvae and juveniles, we successfully sequenced fulllength (782 bp) cytochrome $b$ fragments from a total of 2534 juvenile rockfish collected in 144 hauls, including 105 from the NH-100 station. We identified 20 species according to our high-confidence stringency criterion (Suppl. Fig. 3), and confidently assigned a large number (1489 individuals, $58.7 \%$ ) of specimens to the multispecies WEVZ complex. Another 213 unknowns could not be assigned at high confidence and were coded as unassigned. Using the low-confidence (>50\% bootstrap) criterion, we were able to identify 24 species (Fig. 2, Suppl. Fig 3 and assign many of the previous unknowns to the WEVZ group. The remaining 25 unknowns could not be assigned at low confidence and were coded as unassigned.

Of the species that occurred in the set of lowconfidence identifications that were not found in the high-confidence set, 3 were represented by a single individual (aurora rockfish, $S$. aurora; rosy rockfish, $S$. rosaceus) or a few individuals (darkblotched rockfish, 3 individuals). Only the splitnose rockfish was present in greater numbers (43 individuals). Other differences between the sets of high- and low-confidence identifications were proportions of individuals that were assigned to individual species versus the multispecies 


\section{Table 1}

Correlation matrix of average monthly values for temperature (T) and salinity (S) at the sea surface $(1 \mathrm{~m})$ and the depth of $30 \mathrm{~m}$ at sampling stations and for large-scale environmental indices off Oregon and Washington during 2005-2008. Pearson's correlation coefficients appear below and associated $P$-values are given above the diagonal. The environmental indices include the Upwelling Index (UI) measured off Oregon and Washington and the Pacific Decadal Oscillation (PDO) and North Pacific Gyre Oscillation $(\mathrm{NPGO})$ indices. Bold values indicate significant correlations $(P<0.05)$. SST=sea-surface temperature; SSS=sea-surface salinity.

\begin{tabular}{|c|c|c|c|c|c|c|c|}
\hline & SST & SSS & $30-\mathrm{m} \mathrm{T}$ & $30-\mathrm{m} \mathrm{S}$ & UI & PDO & NPGO \\
\hline $\mathrm{SST}$ & - & 0.645 & 0.155 & 0.880 & 0.703 & 0.160 & 0.921 \\
\hline SSS & 0.12 & - & 0.498 & 0.011 & 0.758 & 0.149 & 0.850 \\
\hline $30-\mathrm{m} \mathrm{T}$ & 0.35 & 0.17 & - & 0.621 & 0.827 & 0.137 & 0.003 \\
\hline $30-\mathrm{m} \mathrm{S}$ & 0.04 & 0.58 & 0.13 & - & 0.599 & 0.337 & 0.283 \\
\hline UI & -0.10 & 0.08 & 0.06 & 0.13 & - & 0.366 & 0.112 \\
\hline PDO & 0.35 & -0.35 & -0.36 & -0.24 & 0.23 & - & 0.101 \\
\hline NPGO & 0.03 & -0.05 & -0.66 & -0.27 & -0.39 & -0.40 & - \\
\hline
\end{tabular}

complex or unidentified. The WEVZ complex accounted for $58 \%$ of the high confidence, and $59 \%$ of the low-confidence data sets, respectively. Because the differences between sets were mainly differences of proportion rather than differences of identity, we chose to perform environmental analyses combining and using both high and low-confidence identification results.

There was some overlap between species identified by using morphological versus molecular techniques, with 12 species identified in both data sets (Fig. 2). However, both approaches also identified species that were not identified with the other method. Five species, the brown rockfish, Puget Sound rockfish, chilipepper (S. goodei), grass rockfish (S. rastrelliger), and pygmy rockfish, were identified only by visual means, whereas 12 species were identified only with the molecular technique (Fig. 2). Thus, the combined approach allowed us to identify a total of 29 species in our data set, plus those samples identified as belonging to the WEVZ complex.

\section{Environmental data}

During the 4 years of our study (2005-2008), ocean conditions during May-October off Oregon and Washington varied in terms of temperature, salinity, and upwelling intensity (Suppl. Fig. 4). Cooler average SST with low variation occurred in $2005\left(13.9^{\circ} \mathrm{C}\right.$ [standard deviation (SD) 1.7]) and $2006\left(14.1^{\circ} \mathrm{C}\right.$ [SD 1.3]) than in 2007 and $2008\left(16.1^{\circ} \mathrm{C}\right.$ [SD 2.0] and $14.2^{\circ} \mathrm{C}$ [SD 1.9], respectively). Warmest $\mathrm{SST}$ were measured during June-September 2007. At 30-m depth, warmest temperatures occurred in 2005, a year considered anomalous owing to delayed upwelling (Barth et al., 2007). Although the start of upwelling was delayed in 2005, once initiated in mid-July, it was strong and persistent, leading to cross-shelf transport of surface waters.
Upwelling was strongest during June-August in 2006, which likely impacted offshore larval dispersal. Salinity varied little at $30 \mathrm{~m}$ during the study, but at the surface, freshwater input from the Columbia River was most detectable during May-June 2005, when upwelling was delayed.

Large-scale indices (PDO and NPGO) displayed values considered more favorable for productivity (more negative PDO and more positive NPGO; Chenillat et al., 2012; Sydeman et al., 2014) in the California Current system during 2007-2008 than during 2005-2006, reflected in the highest rockfish density occurring during 2007 and 2008 (Suppl. Fig. 5). In 2008, PDO values were the most negative and NPGO values the most positive throughout the entire sampling period (MayOctober), indicating that cool productive ocean conditions, coupled with less cross-shelf transport than in 2005 and 2006, were favorable for rockfish prerecruits in 2008. On average, total catches during 2007-2008 $(59,779$ rockfish) were $>3$ times larger than catches during 2005-2006 (18,628 rockfish). Effort was similar during the 2 time periods (129 hauls during 2005-2006 and 142 hauls during 2007-2008). Highest densities of late-larval and juvenile rockfish (identified and unidentified) were sampled in August and September of all years. Ten species/complexes accounted for $>80 \%$ of the genetically identified rockfish over the entire study period (Suppl. Fig. 6).

Correlations between mean monthly temperature, salinity, and the large-scale environmental indices were low (coefficient of determination $\left[r^{2}\right]=0.002-$ 0.436 ); therefore all were retained for inclusion in the community analysis (Table 1). Correlation coefficients between salinity at the surface and at 30-m depth were positively and significantly correlated (coefficient of correlation $[r]=0.58, P=0.011)$ and negatively correlated between temperature at $30 \mathrm{~m}$ and the NPGO $(r=-0.66$, 


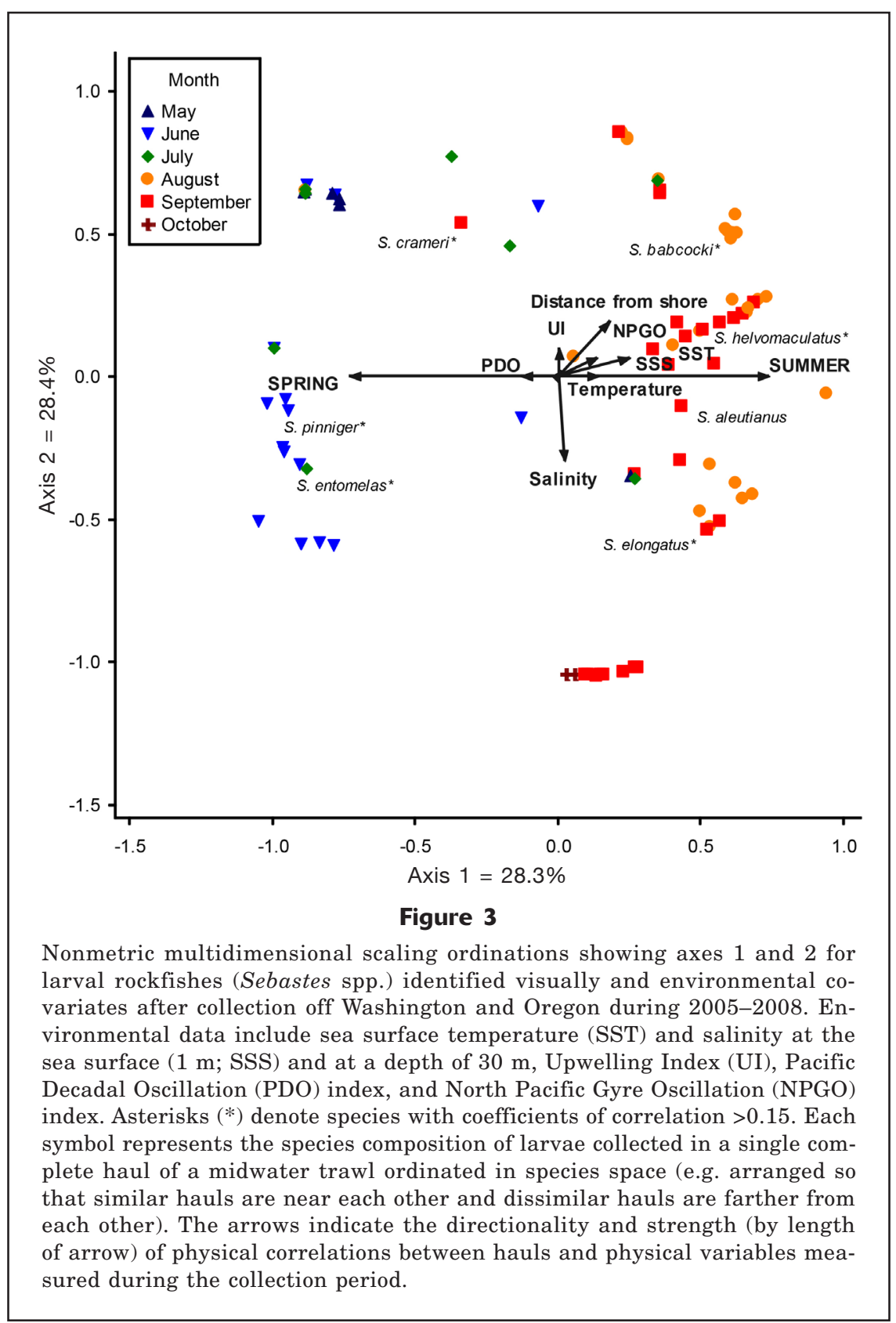

$P=0.003)$. However, because each variable represented a unique spatial scale or in situ habitat, they were all retained for subsequent analysis.

\section{Community analyses}

The NMS ordination of rockfishes identified by visual means (Figs. 3 and 4) contained 7 species caught in 89 of 93 tows where we had visual identifications, and described $73.8 \%$ of the variation in the data set (axis $1=28.3 \%$, axis $2=24.8 \%$, and axis $3=20.6 \%$ ). The stress for the final solution was 17.0 (instability=0, 158 iterations), considered fair but interpretable (Kruskal, 1964). The largest variation in community structure was explained by seasonal differences along axis 1 (Suppl. Table 1). Summer months (July through October, $r=0.767)$ and warmer SST at $1 \mathrm{~m}(r=0.446)$ were positively correlated with axis 1 scores; spring months (May and June) were negatively correlated $(r=-0.767)$. The species most likely to be present during warm, summer months was the rosethorn rockfish. During spring, we were more likely to find canary rockfish ( $S$. pinniger), darkblotched rockfish, and widow rockfish. Axis 2 was positively associated with offshore stations $(r=0.394)$ and negatively associated with warmer temperatures at $50 \mathrm{~m}$, indicating that axis 2 differentiated between on-shelf and off-shelf catches. At offshore stations, we were more likely to encounter redbanded 


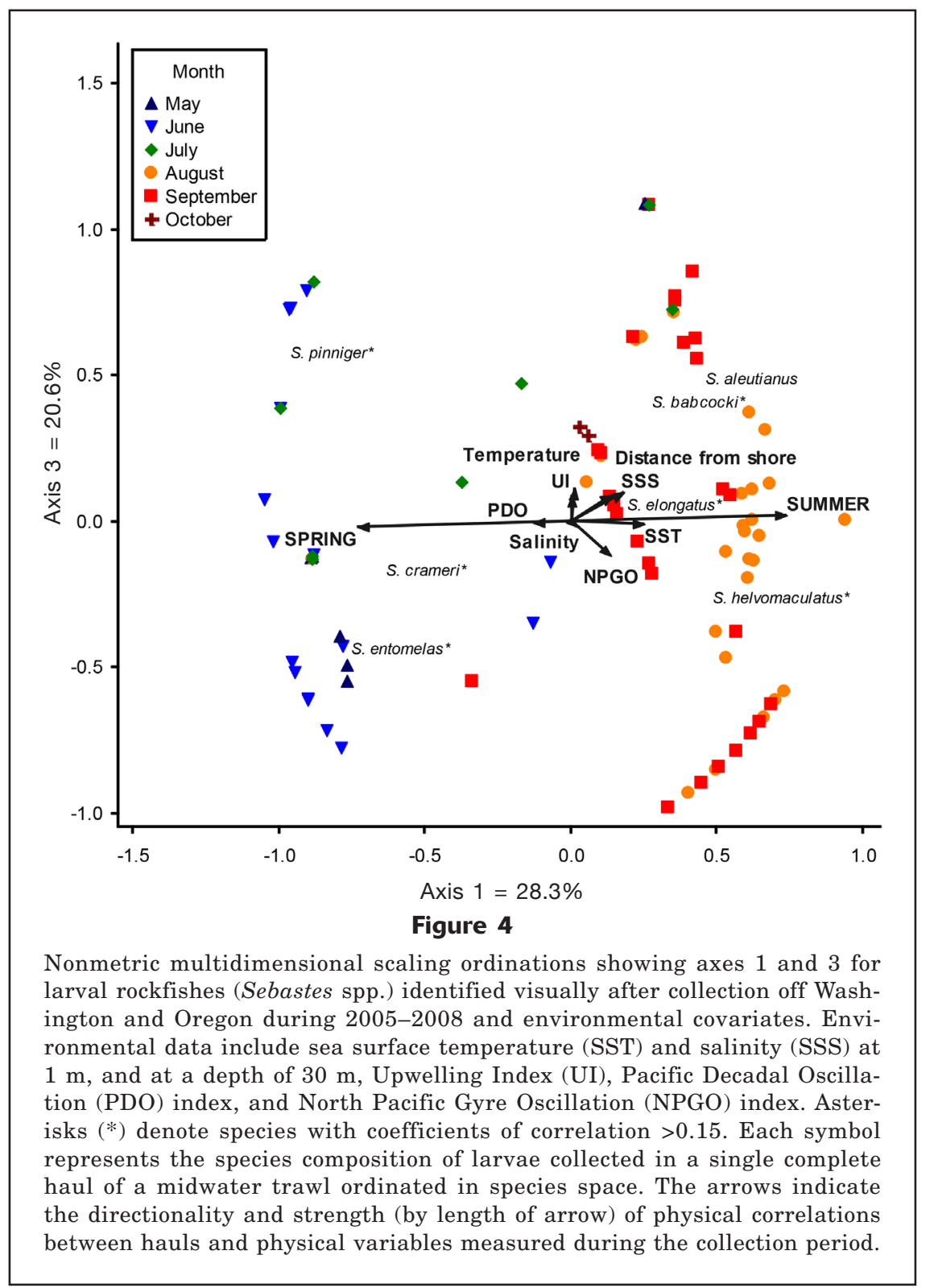

rockfish, whereas greenstriped rockfish were identified closer to the shelf break.

The NMS ordination of the proportion of rockfish identified by genetics (Figs. 5 and 6) contained 24 species caught in 126 of 143 tows where we had genetic data (excluding the station sampled $185 \mathrm{~km}$ offshore) and described $87.3 \%$ of the variation in the data set (axis $1=38.9 \%$, axis $2=29.5 \%$, and axis $3=18.9 \%$ ). The stress for the final solution was $15.7 \%$ (instability=0, 131 iterations). The largest variation in community structure was also explained by seasonal differences along axis 1 (Suppl. Table 2). Summer months $(r=0.729)$ and warmer SSTs $\left(r=0.416, r^{2}<0.15\right)$ were positively associated with axis 1 along with redstripe rockfish ( $S$. proriger), greenstriped rockfish, and yelloweye rockfish (S. ruberrimus) ( $r$ : 0.513, 0.482, and
0.445 , respectively). Axis 1 was negatively associated with spring months ( $r=-0.761)$ and canary) and widow rockfish $(r$ : -0.688 and -0.592$)$. These were 2 of the species that were also identified in spring using visual identification, indicating that there was good agreement between visual and genetic identifications. Axis 2 showed a positive association with redstripe rockfish $(r=0.776)$ and a negative association with rosethorn rockfish $\left(r=-0.745, r^{2}<0.15\right)$, which was associated with warm, summer months based on the visual identification criteria. There were no physical variables associated with axis 2 or 3 , but splitnose rockfish was negatively associated with axis $3(r=-0.552)$.

Rockfish parturition timing varies seasonally by species. To better understand some of this variation, we conducted indicator species analysis to identify 


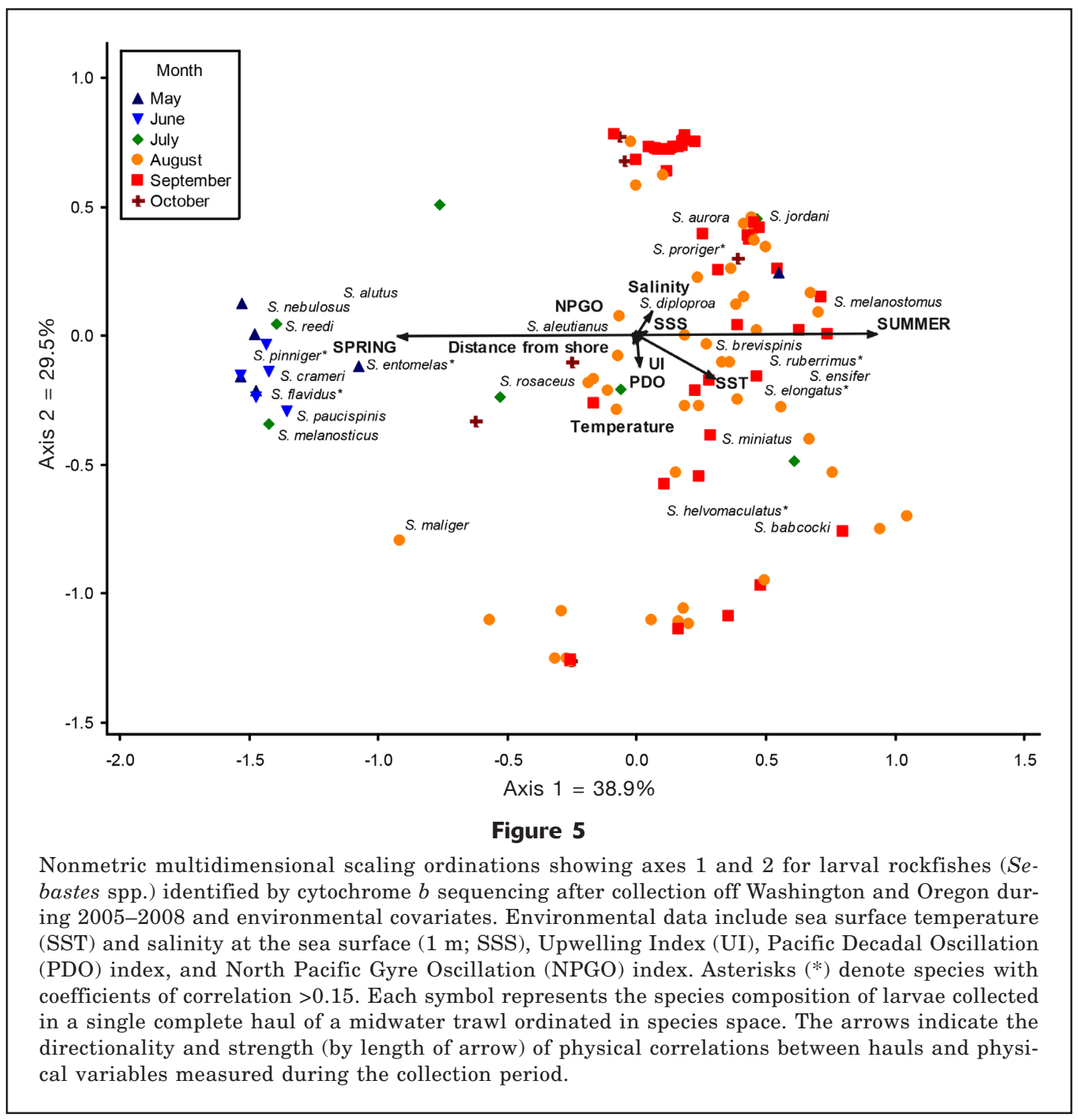

species' affinities to particular months and years (Table 2). Although month and year analyses were performed separately, results are combined in the table. In 2007 and 2008, years previously identified as having high mean concentrations ( $>60$ individuals $/ 1000$ $\mathrm{m}^{3}$ ) of rockfish larvae in the northern California Current ecosystem (Auth, 2011), we identified the rosethorn rockfish as an indicator species. This species was also more likely to be sampled in summer (August). Two of the species that were strongly associated with spring months (May and June) in NMS ordinations (canary and widow rockfish) were also significant indicators in spring months. Another spring indicator species that was not included in NMS ordinations was the yellowtail rockfish ( $S$. flavidus). The NH-100 station was sampled only once during the study, in June 2008. Because widow and yellowtail rockfish were identified as significant indicator species in June and were identified in high abundance from the NH-100 station sampled in 2008 , these results suggest that widow and yellowtail rockfish either spawn far off the shelf, were more abundant, or were more susceptible to offshore advection than other spring spawning species in 2008.

The spatial distribution patterns of the dominant rockfish taxa for selected cruises showed much overlap overall (Suppl. Figs. 7-9). The redstripe rockfish was found mainly later in the summer and predominantly at the outer stations at the shelf break and beyond, although the $\mathrm{NH}$ transect had high catches some years at the inshore station (Suppl. Fig. 7). In contrast, the greenstriped rockfish tended to show lower abundances and were caught almost exclusively beyond the shelf break (Suppl. Fig. 8). The rosethorn rockfish had a patchy distribution, but there were indications for some cruises that sampling did not extend far enough offshore to capture the full distribution of this species (Suppl. Fig. 9). 


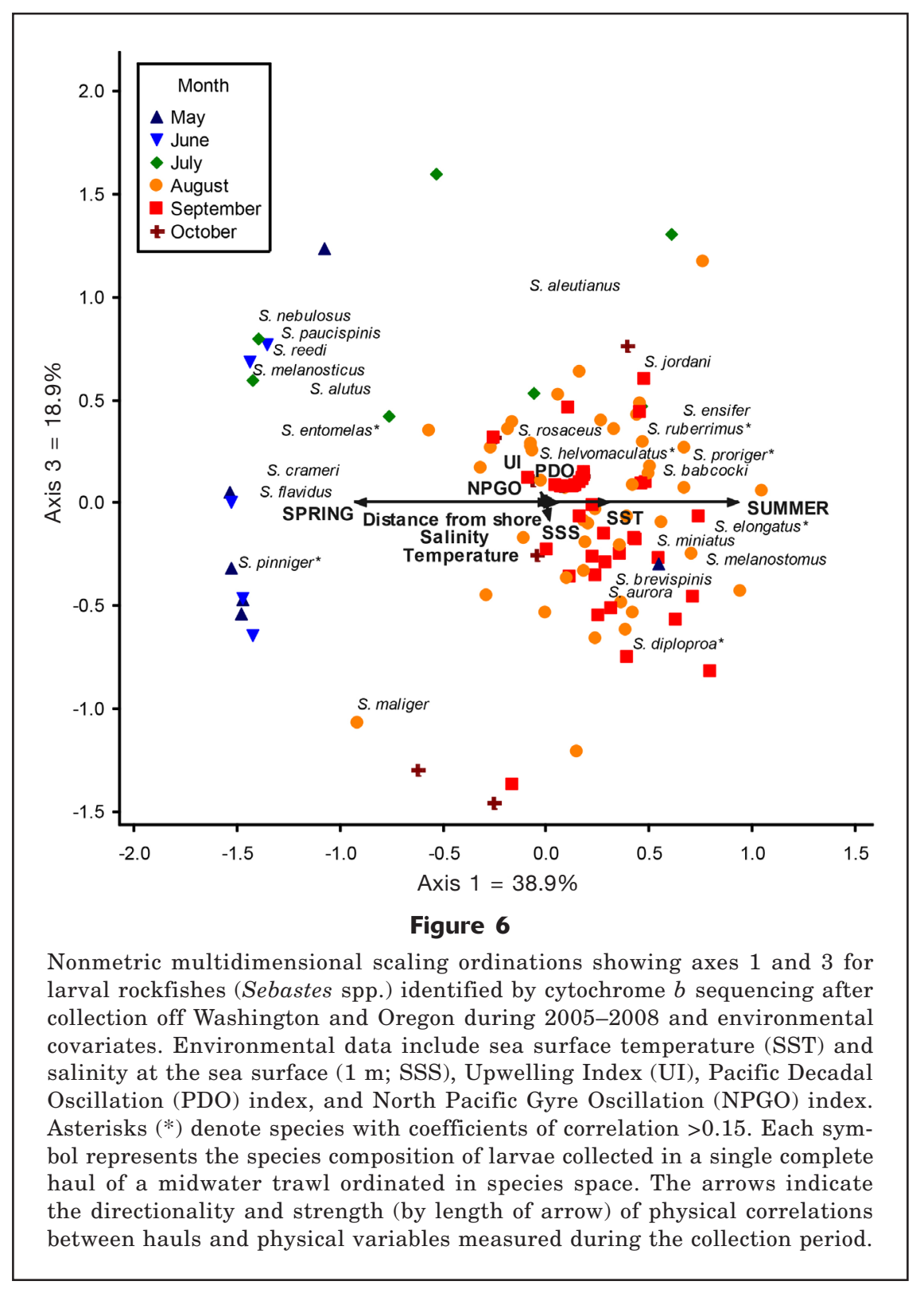

\section{Discussion}

Before the widespread use of DNA-based identifications, much of what was known about larval and juvenile rockfishes off the west coast of North America came from bycatch in multiyear seasonal surveys made in the 1960 s and 1970 s by using strictly visual identifications (Richardson and Laroche, 1979; Laroche and Richardson, 1980, 1981). These authors used a variety of gear to sample both pelagic larvae and juveniles, as well as settled juveniles, providing useful information on the sizes and dates of occurrence and some information on spatial distribution for 7 common species, including several examined here. Using a similar approach, we were able to identify a total of 3266 rockfish from 17 species, using visual methods alone, acknowl- edging that visual identification is more commonly applicable for larger size classes. Previous studies found seasonal patterns similar to those we observed, in that darkblotched, canary, widow, and yellowtail rockfish were generally present early in the summer and settled by the end of June, whereas rosethorn rockfish reached peak catches later in the summer (July and August) (Richardson and Laroche, 1979; Laroche and Richardson, 1980, 1981). Building on the earlier studies, we were able to provide information on a larger number of taxa (24) by using both genetic and visual approaches than by visual identifications alone (17) and to capture a broader size range of juveniles given the larger nets used in our study compared with those used in earlier studies. Because the list of species identified with the 2 methods did not overlap completely, the combined ap- 


\section{Table 2}

Results of the analysis of indicator species for species of Sebastes identified either visually or on the basis of genetics for samples collected off Oregon and Washington during 2005-2008, by month or year in which samples were collected. Separate analyses were conducted for months and years. Results are combined here for ease of presentation. Only the species that had significant $(P<0.05)$ indicators for a particular month or year are shown.

\begin{tabular}{lccc}
\hline & Indicator value & $P$-value & Month or year \\
\hline $\begin{array}{l}\text { Visual identification } \\
\text { S. helvomaculatus }\end{array}$ & $59.0 / 34.3$ & $0.0002 / 0.002$ & August 2008 \\
Genetic identification & & & \\
S. pinniger & 38.2 & 0.002 & May \\
S. entomelas & 37.4 & 0.003 & June \\
S. flavidus & 33.3 & 0.002 & June \\
S. helvomaculatus & 22.7 & 0.009 & 2007 \\
S. babcocki & 16.7 & 0.001 & 2007 \\
& & &
\end{tabular}

proach allowed us to identify a total of 29 species in our samples, and to assign individuals to the WEVZ complex. Of those 29 species, 5 were identified only in the morphological collection, whereas only 12 appeared in the molecular data set. We could also examine annual patterns and seasonal patterns in the presence or absence of larval and juvenile stages of specific rockfish species for spring and summer and relate these to environmental variables at local and regional scales (both cross- and along-shelf scales).

With the publication of mitochondrial and nuclear sequences from 105 of the 110 then-described Sebastes species (Taylor et al., 2004; Hyde et al., 2007), it became possible to identify larval juveniles at any size. Sequence-based identification methods have been previously used to identify morphologically unidentifiable rockfish larvae and to relate distributions of these larvae to oceanographic features and natal habitat (Taylor et al., 2004; Hitchman et al., 2012; Thompson et al., 2016; Thompson et al., 2017), to describe the early development of larval rockfishes (Watson et al., 2016), and to describe the early life history among lesser-known species (Yu et al., 2015). As with previously published research in Southern California utilizing cytochrome $b$ sequencing, we identified 2509 rockfish from 24 different taxa and the 4-species WEVZ complex (plus 25 unknowns), and therefore adding this approach greatly increased the level of species identification and distribution details that could be made available.

Given the difficulty or impossibility of visually identifying the earliest life stages of larval rockfish, genetic approaches offer a way to explore the diversity of important previously unidentifiable rockfish species, thus providing new information on the timing of pelagic larval and juvenile stages and distribution of these previously unexamined species. For example, NMS and our observations from the indicator species analysis that the canary, darkblotched, and widow rockfish are more common among spring samples and the rosethorn rockfish is more prevalent in summer, revealed a clear relationship between abundances of certain species and the time of year sampled. Although some of these patterns have been previously identified, we were able to expand our identifications to include a much greater diversity of species, including many of those that are unidentifiable by visual means. This newly described diversity was then related to environmental factors, such as ocean temperature, upwelling intensity, and productivity regime (PDO and NPGO indices), and season to explore temporal and spatial drivers of species diversity or mating success (Taylor et al., 2004; Thompson et al., 2016; Thompson et al., 2017). Although a detailed seasonal and annual analysis of the abundance and distribution patterns of rockfish species is beyond the scope of this study, we did observe some months and years where individual species showed greater prominence through the indicator species analysis. The years examined in this study showed substantial differences in their oceanographic conditions which may have greatly affected the cross-shelf and along-shore distributions of rockfishes (Brodeur et al., 2006; Ralston and Stewart, 2013).

Previous research on ichthyoplankton diversity and concentration in the eastern North Pacific has shown spatial variation at the local (Richardson et al., 1980; Auth and Brodeur, 2006) and regional scale (Thompson et al., 2014) and temporal variation over the shortand long-term (Brodeur et al., 2008; Auth et al., 2011; Thompson et al., 2014), all of which are influenced by regional and basin-wide environmental fluctuations (Auth et al., 2011; Auth and Brodeur, 2013). One unifying feature of much of this previous research is that some groups of larval fishes cannot be identified to the species level based on pigmentation or meristics. These unidentifiable groups include larval smelts (7 species in the family Osmeridae), rockfishes (65 species), sanddabs (2 species of the genus Citharichthys), and snailfishes (17 species of the genus Liparis) (Richardson et al., 1980; Matarese et al., 1989; Love et al., 
2002; Auth et al., 2011). Our work off the coast of Oregon, like previous research in and around Southern California (Taylor et al., 2004; Thompson et al., 2016; Thompson et al., 2017), has helped illuminate the diversity of the largest of these previously unidentifiable groups of fishes.

Because of the distributional patterns we observed, we may not have sampled the offshore extent of a number of our late-larval rockfishes sufficiently because the highest catches often were found at the most offshore station along our transects. Many species spawn well offshore and move progressively shoreward as they age before finally settling in most cases in demersal habitat over the continental shelf (Laroche and Richardson, $1980 ; 1981)$. Time constraints precluded us from sampling beyond our normal sampling grid during most cruises. However, on one occasion in June 2008, we were able to trawl at a station $185 \mathrm{~km}$ offshore along the Newport transect (Fig. 1). This single trawl tow sampled more than $60 \mathrm{~km}$ farther offshore than our target stations and captured 20,756 rockfish, which were mostly late-larval individuals and too small to be visually identified. We were able to run genetic analysis on a subsample from that haul of 105 individuals that were identified as mostly widow and yellowtail rockfish. In a study of larval fish distribution out to $364 \mathrm{~km}$ from shore along the Newport transect and from another transect off Northern California, Auth (2009) found that the majority of Sebastes larvae were seaward of $120 \mathrm{~km}$ during the spring of 2007, but were closer to the shore during the summer months. However, as acknowledged by the author, because the larvae could not be identified to species, these shifts in regional observations could be confounded by differences in cryptic species not observed in that study. Stable isotope analysis of juvenile rockfish caught on the continental shelf also revealed that they had derived much of their previous nutrition from taxa found off the shelf, indicating potential onshore advection before settlement (Bosley et al., 2014). However, as postulated by Kamin et al. (2014) for a Gulf of Alaska population of Pacific ocean perch (S. alutus), these offshore populations may be subjected to substantial mortality and only a small fraction of the larvae may subsequently return to shelf nursery areas.

Because some closely related groups of rockfishes are still undergoing lineage sorting (Hyde and Vetter, 2007) or may experience mtDNA introgression (Pearse et al., 2007), it was not possible to confidently identify some individuals to species. In our sampling, the WEVZ complex represented a substantial proportion of the larval catch, and is a still-unresolved diversity of species. Although microsatellites represent one approach to separate this (and potentially other multispecies complexes) (Pearse et al., 2007), microsatellite peak sizes can vary between sequencers and PCR chemistries, and therefore would require standardization between different laboratories to produce useful data (Weeks et al., 2002; Moran et al., 2006). This need for standardization makes it more difficult to compare and use microsatellites in databases of known samples than to use DNA sequences, as used here. Ultimately, the development of a suite of linked diagnostic singlenucleotide polymorphisms from genomes of all the members of the genus Sebastes (microhaplotypes) may prove most effective for confidently identifying any species by a molecular approach.

Our study combines the relative speed and ease of visually identifying more distinctive species of rockfish with the power of current sequence-based genetic identification methods. This combined approach provides new information on the distribution and seasonal timing of pelagic and larval juvenile stages of several rockfish species which have been challenging to identify on the basis of traditional morphological metrics and pigmentation. However, there remain some species (i.e., the WEVZ complex) that cannot be resolved to species level with the cytochrome $b$ database of known samples. Analysis down to the species level for collections that contain a high proportion of rockfish (e.g., Thompson et al., 2016) can provide valuable information for ecosystem-based fishery management. Identifying Sebastes larvae to species may allow estimates of spawning biomass of the more abundant species (Ralston et al., 2003; Ralston and MacFarlane, 2010) and enable managers to track recruitment over time (Ralston et al., 2013). As the availability of high throughput sequencers bring the cost per sample down substantially, molecular identification of rockfish species should become more commonplace in the future.

\section{Acknowledgments}

The authors particularly thank the captain and crew of the FV Piky for their assistance with sampling. This research was funded by the NWFSC Stock Assessment Improvement Program; the Oregon State University Cooperative Institute for Marine Resources Studies; the National Science Foundation Research Experiences for Undergraduates program; and the NWFSC Conservation Biology Division. We especially thank A. Thompson, G. DiNardo, T. Auth, and 4 anonymous reviewers, whose helpful comments greatly improved the manuscript.

\section{Literature cited}

Auth, T. D.

2009. Importance of far-offshore sampling in evaluating the ichthyoplankton community in the northern California Current. CalCOFI Rep. 50:107-117.

2011. Analysis of the spring-fall epipelagic ichthyoplankton community in the northern California Current in 2004-2009 and its relation to environmental factors. CalCOFI Rep. 52:148-167.

Auth, T. D., and R. D. Brodeur.

2006. Distribution and community structure of ichthyoplankton off the coast of Oregon, USA, in 2000 and 2002. Mar. Ecol. Prog. Ser. 319:199-213. Article 
2013. An overview of ichthyoplankton research in the northern California Current region: contributions to ecosystem assessments and management. CalCOFI Rep. 54:107-126.

Auth, T. D., R. D. Brodeur, H. L. Soulen, L. Ciannelli, and W. T. Peterson.

2011. The response of fish larvae to decadal changes in environmental forcing factors off the Oregon coast. Fish. Oceanogr. 20:314-328. Article

Barth, J. A., B. A. Menge, J. Lubchenco. F. Chan, J. M. Bane, A. R. Kirinich, M. A. McManus, K. J. Nielsen, S. D. Pierce, and L. Washburn.

2007. Delayed upwelling alters nearshore coastal ecosystems in the northern California Current. Proc. Nat. Acad. Sci. 104:3719-3724. Article

Boehlert, G. W.

1977. Timing of the surface-to-benthic migration in juvenile rockfish, Sebastes diploproa, off southern California. Fish. Bull. 75:887-890.

Bosley, K. L, T. W. Miller, R. D. Brodeur, K. M. Bosley, A. Van Gaest, and A. Elz.

2014. Feeding ecology of juvenile rockfishes off Oregon and Washington based on stomach content and stable isotope analyses. Mar. Biol. 161:2381-2393. Article

Brodeur, R. D., S. Ralston, R.L. Emmett, M. Trudel, T. D. Auth, and A. J. Phillips.

2006. Anomalous pelagic nekton abundance, distribution, and apparent recruitment in the northern California Current in 2004 and 2005. Geophys. Res. Lett. 33:L22S08. Article

Brodeur, R. D., W. T. Peterson, T. D. Auth, H. L. Soulen, M. M. Parnel and A. A. Emerson.

2008. Abundance and diversity of coastal fish larvae as indicators of recent changes in ocean and climate conditions in the Oregon upwelling zone. Mar. Ecol. Prog. Ser. 366:187-202. Article

Buonaccorsi V. P., C. A. Kimbrell, E. A. Lynn, R. D. Vetter. 2002. Population structure of copper rockfish (Sebastes caurinus) reflects postglacial colonization and contemporary patterns of larval dispersal. Can. J. Fish. Aquat. Sci. 59: 1374-1384. Article

2005. Limited realized dispersal and introgressive hybridization influence genetic structure and conservation strategies for brown rockfish, Sebastes auriculatus. Conserv. Genet. 6:697-713. Article

Chenillat, F., P. Riviére, X. Capet, E. Di Lorenzo, and B. Blanke.

2012. North Pacific Gyre Oscillarion modulates seasonal timing and ecosystem functioning in the California Current upwelling system. Geophys. Res. Lett. 39:L01606. Article

Cowen, R. K., and S. Sponaugle.

2009. Larval dispersal and marine population connectivity. Annu. Rev. Mar. Sci. 1:443-466.

Dauble, A. D., S. A. Heppell, and M. L. Johansson.

2012. Settlement patterns of young-of-the-year rockfish among six Oregon estuaries experiencing different levels of human development. Mar. Ecol. Progr. Ser. 448:143-154. Article

Di Lorenzo, E., N. Schneider, K. M. Cobb, P. J. S. Franks, K. Chhak, A. J. Miller, J. C. McWilliams, S. J. Bograd, H. Arango, E. Curchitser, et al.

2008. North Pacific Gyre Oscillation links ocean climate and ecosystem change. Geophys. Res. Lett. 35:L08607. Article
Di Lorenzo E., K. M. Cobb, J. C. Furtado, N. Schneider, B. T. Anderson, A. Bracco, M. A. Alexander, and D. J. Vimont. 2010. Central Pacific El Niño and decadal climate change in the North Pacific. Nat. Geosci. 3:762-765. Article

Dufrêne, M., and P. Legendre.

1997. Species assemblages and indicator species: the need for a flexible asymmetrical approach. Ecol. Monogr. 67:345-366. Article

Emmett, R. L., R. D. Brodeur, and P. M. Orton.

2004. The vertical distribution of juvenile salmon (Oncorhynchus spp.) and associated fishes in the Columbia River plume. Fish. Oceanogr. 13:392-402. Article

Felsenstein, J., and G. A. Churchill.

1996. A hidden Markov model approach to variation among sites in rate of evolution. Mol. Biol. Evol. 13:93104. Article

Gadgil, M.

1971. Dispersal: population consequences and evolution. Ecology. 52:253-261. Article

Gharrett, A. J., A. K. Gray, and J. Heifetz.

2001. Identification of rockfish (Sebastes spp.) by restriction site analysis of the mitochondrial ND-3/ND-4 and 12S/16S rRNA gene regions. Fish. Bull. 99:49-62.

Gray, A. K., A. W. Kendall Jr., B. L. Wing, M. G. Carls, J. Heifetz, Z. Li, and A. J. Gharrett.

2006. Identification and first documentation of larval rockfishes in southeast Alaskan waters was possible using mitochondrial markers but not pigmentation patterns. Trans. Am. Fish. Soc. 135:1-11.

He, X., J. C. Field, D. E Pearson, L. Lefebvre, S. Lindley.

2015. Status of bocaccio, Sebastes paucispinis, in the Conception, Monterey and Eureka INPFC areas for 2015, 270 p. Pacific Fishery Management Council, Portland, OR. [Available from website.]

Hitchman, S. M., N. B. Reyns, and A. R. Thompson.

2012. Larvae define spawning habitat of bocaccio rockfish Sebastes paucispinis within and around a large southern California marine reserve. Mar. Ecol. Prog. Ser. 465:227-242. Article

Hyde, J. R., and R. D. Vetter.

2007. The origin, evolution, and diversification of rockfishes of the genus Sebastes (Cuvier). Mol. Phylogenet. Evol. 44:790-811. Article

Ivanova, N. V., J. R. Dewaard, and P. D.N . Hebert.

2006. An inexpensive, automation-friendly protocol for recovering high-quality DNA. Mol. Ecol. Notes, 6:9981002. Article

Johansson, M. L., M. A. Banks, K. D. Glunt, H. M. HasselFinnegan, and V. P. Buonaccorsi.

2008. Influence of habitat discontinuity, geographical distance, and oceanography on fine-scale population genetic structure of copper rockfish (Sebastes caurinus). Mol. Ecol. 17:3051-3061. Article

Kamin, L. M., K. J. Palof, J. Heifetz, and A. J. Gharrett.

2014. Interannual and spatial variation in the population genetic composition of young-of-the-year Pacific ocean perch (Sebastes alutus) in the Gulf of Alaska. Fish Oceanogr. 23:1-17. Article

Ko, H. L., Y. T. Wang, T. S. Chiu, M. A. Lee, M. Y. Leu, K. Z. Chang, W. Y. Chen, and K. T. Shao.

2013. Evaluating the accuracy of morphological identification of larval fishes by applying DNA barcoding. PLoS ONE 8:e53451. Article

Kruskal, J. B.

1964. Multidimensional scaling by optimizing goodness 
of fit to a nonmetric hypothesis. Psychometrika 29:1-27. Article

Laidig, T. E., and P. B. Adams.

1991. Methods used to identify pelagic juvenile rockfish (genus Sebastes) occurring along the coast of central California. NOAA Tech. Memo. NMFS-SWFSC-166, 180 p.

Laidig, T. E., J. R. Chess, and D. F. Howard.

2007. Relationship between abundance of juvenile rockfishes (Sebastes spp.) and environmental variables documented off northern California and potential mechanisms for the covariation. Fish. Bull. 105:39-48.

Laroche, W. A., and S. L. Richardson.

1980. Development and occurrence of larvae and juveniles of the rockfishes Sebastes flavidus and Sebastes melanops (Scorpaenidae) off Oregon. Fish. Bull. 77:901-924.

1981. Development of larvae and juveniles of the rockfishes Sebastes entomelas and S. zacentrus (family Scorpaenidae) and occurrence off Oregon, with notes on head spines of S. mystinus, S. flavidus, and S. melanops. Fish. Bull. 79:231-257.

Lasker, R. (ed.).

1985. An egg production method for estimating spawning biomass of pelagic fish: application to the northern anchovy, Engraulis mordax. NOAA Tech. Rep. NMFS 36, 99 p.

Levin, S. A., H. C. Muller-Landau, R. Nathan, and J. Chave. 2003. The ecology and evolution of seed dispersal: a theoretical perspective. Annu. Rev. Ecol. Evol. Syst. 34:575604. Article

Love, M. S., M. Yoklavich, and L. Thorsteinson.

2002. The rockfishes of the northeast Pacific, 405 p. Univ. Calif. Press, Berkeley, CA.

Mantua, N. J., S. R. Hare, Y. Zhang, J. M. Wallace, and R. C. Francis.

1997. A Pacific interdecadal climate oscillation with impacts on salmon production. Bull. Am. Meteorol. Soc. 78:10691079. Article

Matarese, A. C., A. W. Kendall Jr., D. M. Blood, and B. M. Vinter.

1989. Laboratory guide to early life history stages of northeast Pacific fishes. NOAA Tech. Rep. NMFS 80, $652 \mathrm{p}$.

McCune, B., and M. J. Mefford.

2011. PC-ORD. Multivariate analysis of ecological data. Version 6 user's booklet, 25 p. MjM Software, Gleneden Beach, OR. [Available from website.]

McCune, B., J. B. Grace, and D. L. Urban.

2002. Analysis of ecological communities, 304 p. $\mathrm{MjM}$ Software Design, Gleneden Beach, OR.

Moran, P., D. J. Teel, E. S. LaHood, J. Drake, and S. Kalinowski.

2006. Standardizing multi-laboratory microsatellite data in Pacific salmon: an historical view of the future. Ecol. Freshw. Fish 15:597-605. Article

Moser, H. G.

1996. The early stages of fishes in the California Current region. CalCOFI Atlas 33, $1505 \mathrm{p}$.

Moser, H. G., and G. W. Boehlert.

1991. Ecology of pelagic larvae and juveniles of the genus Sebastes. Environ. Biol. Fish. 30:203-224. Article

Paradis E., J. Claude, and K. Strimmer.

2004. APE: analyses of phylogenetics and evolution in $\mathrm{R}$ language. Bioinformatics 20:289-290. Article
Pearse, D. E., L. Wooninck, C. A. Dean, and J. C. Garza.

2007. Identification of northeastern Pacific rockfish using multilocus nuclear DNA genotypes. Trans. Am. Fish. Soc. 136:272-280. Article

Phillips, A. J., S. Ralston, R. D. Brodeur, T. D. Auth, R. L. Emmett, C. Johnson, and V. G. Wespestad.

2007. Recent pre-recruit Pacific hake (Merluccius productus) occurrences in the northern California Current suggest a northward expansion of their spawning area. CalCOFI Rep. 48:215-229.

Phillips, A. J., R. D. Brodeur, and A. V. Suntsov.

2009. Micronekton community structure in the epipelagic zone of the northern California Current upwelling system. Prog. Oceanogr. 80:74-92. Article

$\mathrm{R}$ Core Team.

2016. R: a language and environment for statistical computing. R Foundation for Statistical Computing, Vienna, Austria. [Available from website, accessed June 2016.]

Ralston, S., and B. R. MacFarlane.

2010. Population estimation of bocaccio (Sebastes paucispinis) based on larval production. Can. J. Fish. Aquat. Sci. 67:1005- 1020. Article

Ralston, S. and I.J. Stewart.

2013. Anomalous distributions of pelagic juvenile rockfish on the U.S. West Coast in 2005 and 2006. CalCOFI Rep. 54:155-166.

Ralston, S., J. R. Bence, M. B. Eldridge, and W. H. Lenarz.

2003. An approach to estimating rockfish biomass based on larval production, with application to Sebastes jordani. Fish. Bull. 101:129-146.

Ralston, S., K. M. Sakuma, and J. C. Field.

2013. Interannual variation in pelagic juvenile rockfish (Sebastes spp.) abundance-going with the flow. Fish. Oceanogr. 22:288-308. Article

Richardson, S. L., and W. A. Laroche.

1979. Development and occurrence of larvae and juveniles of the rockfishes Sebastes crameri, Sebastes pinniger, and Sebastes helvomaculatus (family Scorpaenidae) off Oregon. Fish. Bull. 77:1-46.

Richardson, S. L., J. L. Laroche, M. D. Richardson.

1980. Larval fish assemblages and associations in the north-east Pacific Ocean along the Oregon coast, winterspring 1972-1975. Estuar. Coast. Mar. Sci. 11:671-699. Article

Rocha-Olivares, A., C. A. Kimbrell, B. J. Eitner, and R. D. Vetter.

1999. Evolution of a mitochondrial cytochrome $b$ gene sequence in the species-rich genus Sebastes (Teleostei, Scorpaenidae) and its utility in testing the monophyly of the subgenus Sebastomus. Mol. Phylogenet. Evol 11:426-440. Article

Rocha-Olivares, A., H. G. Moser, and J. Stannard.

2000. Molecular identification and description of pelagic young of the rockfishes Sebastes constellatus and Sebastes ensifer. Fish. Bull. 98:353-363.

Sakuma, K. M., and T. E. Laidig.

1995. Description of larval and pelagic juvenile chilipepper, Sebastes goodie (family Scorpaenidae), with an examination of larval growth. Fish. Bull. 93:721-731.

Seeb, L. W., and A. W. Kendall Jr.

1991. Allozyme polymorphisms permit the identification of larval and juvenile rockfishes of the genus $S e$ bastes. Environ. Biol. Fish. 30:191-201. Article 
Sydeman, W. J., S. A. Thompson, M. Garcia-Reyes, M. Kahru, W.T. Peterson, and J.L. Largier.

2014. Multivariate ocean-climate indicators (MOCI) for the central California Current: environmental change, 1990-2010. Prog. Oceanogr. 120:352-369.

Taylor, C. A., W. Watson, T. Chereskin, J. Hyde, and R. Vetter. 2004. Retention of larval rockfishes, Sebastes, near natal habitat in the Southern California Bight as indicated by molecular identification methods. CalCOFI Rep. 45:152-166.

Thompson, A. R., T. D. Auth, R. D. Brodeur, N. M. Bowlin, and W. Watson.

2014. Dynamics of larval fish assemblages in the California Current System: a comparative study between Oregon and southern California. Mar. Ecol. Prog. Ser. 506:193-212. Article

Thompson, A.R., J.R. Hyde, W. Watson, D.C. Chen, and L.W. Guo.

2016. Rockfish assemblage structure and spawning locations in southern California identified through larval sampling. Mar. Ecol. Prog. Ser. 547:177-192. Article
Thompson, A. R., D. C. Chen, L. W Guo, J. R. Hyde, and W. Watson.

2017. Larval abundances of rockfishes that were historically targeted by fishing increased over 16 years in association with a large marine protected area. R. Soc. Open Sci. 4:170639. Article

Watson, W., S. R. Charter, and C. A. Taylor Lawley.

2016. Early larvae of the swordspine rockfish (Sebastes ensifer) identified by molecular methods. Fish. Bull. 114:135-143. Article

Weeks, D. E., Y. P. Conley, R. E. Ferrell, T. S. Mah, and M. B. Gorin.

2002. A tale of two genotypes: consistency between two high-throughput genotyping centers. Genome Res. 12:430-435. Article

Yu, H. J., Y. J. Im, H. S. Jo, S. J. Lee, and J.-K. Kim.

2015. Morphological development of eggs, larvae, and juvenile of Sebastes koreanus (Scorpaeniformes: Scorpaenidae) from the Yellow Sea. Ichthyol. Res. 62:439-449. Article 